\title{
Empati dan Religiositas sebagai Prediktor terhadap Pemaafan pada Mahasiswa Sekolah Tinggi Teologi Salatiga
}

\author{
Sri Lina Betty Lamsihar Simorangkir \\ Sekolah Tinggi Teologi Salatiga, Salatiga, Jawa Tengah, Indonesia \\ srilinasimorangkir67@gmail.com
}

\begin{abstract}
This research was conducted to find out the possibility of empathy and religiosity as a predictor of forgiveness student Sekolah Tinggi Teologi Salatiga. Sample in observational it is student Sekolah Tinggi Teologi Salatiga that total of 71 people. Three types of scale: empathy scale, religiosity scale, and forgiveness scale. All gathered data were processed and analyzed using a parallel linear regression with statistic program windows version 17.00. By a regression analyzing was obtained to usufruct that empathy and religiosity as a predictor of forgiveness the students Sekolah Tinggi Teologi Salatiga. $R^{2}=0.292$, F hitung $=13.999$ significant level of $0.000<0.05$.
\end{abstract}

Keywords: empathy; forgiveness; religiosity; student

\begin{abstract}
Abstrak
Penelitian in bertujuan untuk mengetahui empati dan religiusitas mahasiswa dapat dijadikan prediktor terhadap pemaafan mahasiswa Sekolah Tinggi Teologi Salatiga. Sampel dalam penelitian adalah mahasiswa Sekolah Tinggi Teologi Salatiga yang berjumlah 71 orang. Teknik pengumpulan data dengan menggunakan teknik sampel jenuh atau seluruh mahasiswa yang ada. Ada tiga skala yang digunakan yaitu skala empati, skala religiusitas, dan skala pemaafan. Data yang diperoleh dengan menggunakan analisis regresi melalui program SPSS versi 17.0. Melalui analisis regresi diperoleh hasil bahwa empati dan religiusitas dapat dijadikan sebagai prediktor terhadap pemaafan mahasiswa Sekolah Tinggi Teologi Salatiga. Dengan nilai $R=0,292$, F hitung= 13.999 pada taraf signifikan $0.000<0.05$
\end{abstract}

Kata kunci: empati; mahasiswa; pemaafan; religiositas

\section{PENDAHULUAN}

Topik forgiveness menjadi hangat bagi para peneliti dalam beberapa tahun terakhir ini. Para psikolog telah memberikan perhatian yang berkesinambungan di dalam melaksanakan forgiveness. Lebih dari lima belas tahun terakhir ini, dunia psikologi memberikan perkembangan dalam kemampuan pemeliharaan hubungan interpersonal dan intrapersonal dengan adanya pelanggaran (transgression) (Exline dan Zell, 2009). Forgiveness merupakan salah satu topik dalam psikologi positif yang meneliti dan melihat bagaimana komunitas hidup yang dapat mencapai kualitas lebih baik, bahagia, dapat terhubung 
kembali, dan menyenangkan. Menjadi perhatian, bagaimana manusia dapat menyelesaikan hubungan yang retak pada konflik yang berada dalam perasaan marah berkelanjutan, dendam, benci, menghindar, kesehatan terganggu dengan tekanan darah yang tinggi yang berpengaruh pada jantung? Manusia berusaha mempertahankan hubungan interpersonal yang baik dengan perasaan dikasihi, kepedulian, tidak anarkis, berpikir baik sehingga dapat mencapai tujuan hidup bersama. Hubungan dekat dengan orang lain seringkali menyediakan suatu sumber penting dari kebahagiaan dan kepuasan serta mendukung kesejahteraan (Karremans dan van Lange, 2008). Tampaknya tidak terelakkan bahwa setiap saat dan seterusnya dalam hubungan interpersonal setiap individu dapat merasa terluka dan tersinggung disebabkan pelanggaran.

Bagaimana meresponi transgression dan dapat memakluminya? Transgression menyebabkan beberapa dampak, baik fisik mau pun psikologis, individu cenderung menjadi depresif, fobia, dan mengalami panic disorder, serta dapat mengganggu system saraf simpatis dan kardiovaskuler tubuh. ${ }^{1}$ Respon yang tepat dalam menghadapi transgression yang harus dimiliki individu adalah dengan meningkatkan kesehatan fisik dan psikologisnya. Bagaimana orang memaafkan? Hampir semua orang tidak mengampuni dalam beberapa kali ketika merasakan akibat transgresi. ${ }^{2}$ Fenomena ini disebut forgiveness yang mengacu pada fakta bahwa individu secara subyektif meyakini bahwa hidupnya akan menjadi lebih baik, menyenangkan, hubungan komunikasi yang dipulihkan, dan kesehatan mental juga kesehatan fisik serta kesejahteraan psikologi.

Semua agama besar di dunia mempertimbangkan forgiveness dalam pandangan penganut kepercayaan. ${ }^{3}$ Forgiveness juga dijelaskan sebagai proses psikologis yang rumit ${ }^{4}$ dan relasional tetapi penting dan berguna. Penduduk Amerika pada umumnya ${ }^{5}$ memiliki sikap positif terhadap forgiveness. Beberapa bukti menunjukkan bahwa forgiveness dapat meningkatkan penyesuaian perkawinan $^{6}$, dapat mengurangi depresi dan kecemasan. ${ }^{7}$ Forgiveness merupakan kemampuan individu dengan komponen berkurangnya perasaan untuk menghindar dan membalas dendam serta memiliki niat baik terhadap transgresor.

\footnotetext{
${ }^{1}$ M. E. McCullough, L.M. Root, \& A.D. Cohen, "Writing about the personal benefits of transgression facilitates forgiveness," Journal of Consulting and Clinical Psychology, 74, 887-897, 2006.

${ }^{2}$ N. G.Wade \& E.L. Worthington, "Overcoming interpersonal offenses: Is forgiveness the only way to deal with unforgiveness?” Journal Of Counseling \& Development - Summer, 81, 2003.

${ }^{3}$ E. K. P. Hui, D. Watkins, T.N.Y. Wong, \& R.C.F. Sun, "Religion and forgiveness from Hong Kong chinese perspective,: Pastoral Psychology, 55, 183-195, 2006

${ }^{4}$ E. L. Jr. Worthington, "Empirical research on forgiveness with Christians: What have we learned?" Journal of Psychology and Christianity, 27, 368-370, 2008.

${ }^{5}$ R. L. Gorsuch \& J. Y. Hao, "Forgiveness: an exploratory factor analysis and its relationships to religious variables," Review of religious Research, 34, 333-347, 1993.

${ }^{6}$ M. E. McCullough, E. L. Jr. Worthington, \& K. C. Rachal, "Interpersonal forgiving in close relationship,” Journal of Personality and Social Psychology, 73, 321-336, 1997.

${ }^{7}$ Ibid.
} 
Dalam penelitian yang akan dilakukan saat ini lebih memfokuskan pada forgiveness khususnya mahasiswa Sekolah Tinggi Teologi Salatiga (selanjutnya STTS). STTS merupakan sarana pendidikan calon pendeta yang didatangi dari berbagai pulau di Indonesia. Mahasiswa di Indonesia rata-rata berada pada rentang usia 18 sampai 24 tahun. Untuk STTS yang bernaung pada organisasi Gereja Pantekosta di Indonesia mempunyai kekhasan tersendiri dalam mengikuti pendidikan menjadi pendeta. Batas usia tidak menjadi syarat dalam belajar dan untuk mewujudkan tugas dan panggilan dalam Misi Tuhan Yesus Kristus tetapi untuk belajar sepanjang hayat (long life learning). Sesuai dengan data pendaftaran mahasiswa STTS umumnya berada pada usia 16 sampai 60 tahun.

Studi mengenai forgiveness menjadi penting karena pada periode waktu ini, peristiwaperistiwa dan transisi yang berbeda mungkin memengaruhi perkembangan serta forgiveness mereka. Tiap-tiap batasan usia memiliki kekhasan sebagai individu yang berkembang dengan potensi yang besar lebih menarik dan layak untuk dieksplorasi. Selain itu, individu mengalami penyesuaian diri dengan lingkungan sekitarnya (STTS), dan mulai memilih dan mencoba menanamkan nilai-nilai yang sesuai dan yang dapat diterima oleh masyarakat sekitarnya yang juga berbeda dengan budaya daerahnya. Sebagai generasi yang masih berkembang, merupakan suatu hal yang tepat apabila dilakukan penelitian mengenai bagaimana kemampuan individu dalam forgiveness. Sesuai penelusuran peneliti, kemungkinan penelitian sejenis ini terhadap mahasiswa teologi masih minim. STT Salatiga tidak menjadikan forgiveness sebagai kompetensi siswa untuk dinyatakan lulus dari pendidikan tersebut. Terlibatnya siswa dalam segala aspek kegiatan formal maupun non formal dapat memungkinkan terbukanya perasaan enak ataupun tidak, yang bisa juga menjadi pemicu konflik. ${ }^{8}$ Dari faktor-faktor tersebut, maka dipilih empati dan religiositas sebagai dua variabel yang akan menjadi prediktor bagi forgiveness mahasiswa teologi, karena variabel ini masih sedikit diteliti dalam konteks forgiveness mahasiswa teologi Indonesia, dan mahasiswa teologi Salatiga khususnya.

\section{Kajian Teori}

Dalam melaksanakan pemaafan (forgiveness) terdapat aspek-aspek dan faktor-faktor yang mendukungnya. Bagian ini memberikan penjelasan mengenai forgiveness dan teoriteori yang men-dasari forgiveness, serta bagaimana hubungan forgiveness dengan faktor empati dan faktor religiositas yang menjadi prediktornya.

\section{Konsep dan Teori Pemaafan}

Para peneliti terdahulu telah menggunakan definisi yang berbeda-beda untuk forgiveness. Penelitian empiris pada agama menyatakan bahwa forgiveness telah

\footnotetext{
${ }^{8}$ K. A. Lawler-Row, J. W. Younger, R. L. Piferi, W. H. Jones, "The role of adult attachment style in forgiveness following an interpersonal offense," Journal of Counseling \& Development, 84, 493-500, 2006.
} 
dipromosikan lebih dari seribu tahun dan telah dibantu menentukan definisinya melalui budaya. Di samping itu, agama telah memengaruhi proses psikologi untuk memberi definisi tentang forgiveness. ${ }^{9}$ Dalam tradisi Kristen, forgiveness didasarkan pada pengalaman pengampunan ilahi, sehingga forgiveness dianggap berada dalam pusat keyakinan Kristen. ${ }^{10}$ Bukti yang mendukung hal ini dinyatakan oleh McCullough dan Worthington, bahwa individu yang religius menilai forgiveness lebih dapat dilakukan daripada individu yang tidak religius. ${ }^{11}$

Pemaafan adalah sebuah perubahan prososial intraindividu terhadap transgresor yang ditetapkan dalam sebuah hubungan yang khusus ${ }^{12}$ serta perubahan prososial dalam motivasi untuk menghindari atau membalas dendam kepada transgresor. ${ }^{13}$ Dipertegas lagi, McCullough, Bono, dan Root ${ }^{14}$, forgiveness adalah rangkaian perubahan prososial dalam motivasi individu terhadap pelanggaran interpersonal dimana individu menjadi tidak terlalu menjauh (less avoidant) dan tidak terlalu mendendam (less vengeful) terhadap transgresor (dan mungkin, menjadi bersikap lebih baik - more benevolent). Enright dan Coyleserta Enright, Gassin, dan $\mathrm{Wu}$ mendefinisikan forgiveness sesuai pendapat seorang filosof yang bernama J. North, yaitu kemampuan untuk melihat transgresor dengan penuh iba, kebajikan dan kasih dan dengan sengaja mengabaikan haknya. ${ }^{15}$ Kebanyakan ahli kelihatannya setuju bahwa forgiveness adalah proses perubahan motivasi dimana individu menjadi lebih positif dan membuang yang negatif (yakni menghindar - avoidance, dan balas dendam - revenge) pada individu yang telah merugikannya di masa lalu. ${ }^{16}$

Dari beberapa definisi di atas, maka definisi yang digunakan yaitu memaafkan segala kekeliruan masa lalu yang menyakitkan dengan berbuat baik, tidak memiliki rasa dendam dan, menghentikan sikap menghindar dengan emosi yang positif.

\footnotetext{
${ }^{9}$ A. Macaskill, "Defining forgiveness: Christian clergy and general population perspectives," Journal of Personality.73, 1238-1263, 2005.

${ }^{10}$ Ibid.

${ }^{11}$ M. E. McCullough, E. L. Jr. Worthington, \& K. C. Rachal, "Interpersonal forgiving in close relationship,"

${ }^{12}$ M. E. McCullough, G. Bono, \& L.M. Root, "Religion and forgiveness," Dalam R. F. Paloutzian \& C. L. Park (Eds.), Handbook of the psychology of religion and spirituality (pp. 394-411). New York: The Guilford Press, 2005

${ }^{13}$ A. Macaskill, "Defining forgiveness: Christian clergy and general population perspectives"

${ }^{14}$ S. J. Sandage \& I. Williamson, "Relational spirituality and dispositional forgiveness: a structural equations model," Journal of Psychology and Theology, 38, 255-266, 2010.

${ }^{15}$ R. D. Enright, \& C. T. Coyle, "Researching the process model of forgiveness within psychological interventions,'Dalam E. L. Wothington, Jr. (Ed.), Dimensions of forgiveness: Psychological research and theological perspectives (pp.139-161). Philadelphia: Templeton Foundation Press, 1998. Band: R. D. Enright, E. A. Gassin, \& C. Wu, "Forgiveness: A development view," Journal of Moral Development, 21, 99-114, 1992

${ }^{16}$ E. L. Jr. Worthington, Handbook of forgiveness (New York: Routledge, 2005). Band: McCullough, Root, \& Cohen, "Writing about the personal benefits of transgression facilitates forgiveness."
} 
McCullough menentukan forgiveness sebagai konstelasi motivasi prososial. ${ }^{17}$ Individu dimotivasi untuk menghindari pembuat kesalahan dan untuk membalas dendam. Selanjutnya saat melaksanakan forgiveness, ingatan kepada transgresor dan kejahatannya tidak lagi memotivasi mereka terhadap perilaku tersebut. Worthington, Sharp, Lerner dan Sharp menyatakan bahwa motif dalam hidup individu sering bersaing dan dapat bertransformasi. ${ }^{18}$ Penggantian emosional (emotional replacement) yaitu penggantian emosi negatif dengan emosi positif dapat berkontribusi untuk mengubah motif. Emosi positif sering berbaur bersama-sama untuk membentuk ekspresi yang kompleks dan emosi negatif berbaur untuk membentuk ekspresi negatif yang kompleks pula. ${ }^{19}$

Ketika berada pada emosi negatif yang meliputi kemarahan, ketakutan, kebencian, permusuhan, kepahitan, maka tidak ada forgiveness (Worthington dan Scherer, 2004). Pengalaman sejumlah emosi positif diperlukan untuk menetralkan unforgiveness sehingga forgiveness bisa terjadi pada sebagian saja atau sepenuhnya. Sesuai pendapat Worthington, Sharp, Lerner, dan Sharp, menyatakan ketika diberi stimulus setelah suatu pelanggaran, maka motivasi terpicu untuk hadir dan (mungkin) bertindak pada basis kebajikan. ${ }^{20}$ Dengan demikian, motif balas dendam diubah dengan motif belas kasihan, kasih karunia, altruisme, konsiliasi, dan cinta.

Dari beberapa teori yang dinyatakan seperti di atas maka peneliti menggunakan teori McCullough karena individu akan melakukan forgiveness jika memiliki motivasi yang dapat memengaruhi emosi.

\section{Empati}

Eisenberg menyatakan bahwa empati adalah sebuah respon afektif yang berasal dari penangkapan atau pemahaman keadaan emosi atau kondisi lain dan yang mirip dengan perasaan orang lain. ${ }^{21}$ Empati juga sebagai kemampuan untuk meletakkan diri sendiri dalam posisi orang lain dan mampu menghayati pengalaman orang lain. Rosenberg mendefinisikan empati adalah suatu usaha untuk memahami di dalam diri individu secara internal dan keadaan emosionalnya. ${ }^{22}$ Dari definisi-definisi di atas, sesuai dengan tujuan penelitian ini, maka definisi empati yang akan digunakan yaitu kemampuan untuk saling memahami pengalaman pikiran, emosi, dan pengalaman langsung dari orang lain sehingga dapat merasakan perasaan dan pikiran orang lain.

\footnotetext{
${ }^{17}$ M. J. A.Wohl, L. DeShea, \& R. L. Wahkinney, "Looking within: measuring state self-forgiveness and its relationship to psychological well-being," Canadian Journal of Behavioural Science, 40, 1-10, 2008.

${ }^{18}$ E. L. Jr. Worthington, C. B. Sharp, A. J.Lerner, \& J.Sharp, "Interpersonal forgiveness as an example of loving one's enemies," Journal of Psychology and Theology, 34, 32-42, 2006.

${ }^{19}$ Ibid.

${ }^{20}$ Ibid.

${ }^{21}$ N. Eisenberg, Empathy and its development (New York: Cambridge University Press, 2002).

${ }^{22} \mathrm{C}$. Bradley, The interconnection between religious fundamentalism, spirituality, and the four dimensions of empathy," Review of Religious research, 51, 201-219, 2008.
} 


\section{Religiositas}

Ada dua alasan yang menyatakan bahwa religiositas adalah sebuah konsep yang rumit dan sulit untuk didefinisikan. Pertama, ketidakpastian dan sifat tidak tepat dari bahasa Inggris. $^{23}$ Bahasa sehari-hari dalam Thesaurus Roget $^{24}$, religiositas ditemukan identik dengan istilah seperti religiositas, ortodoksi, keyakinan iman, kesalehan, pengabdian, dan kekudusan. Kedua, dalam konsep religiusitas melintasi disiplin ilmu, masing-masing definisi mendekati titik pandang yang berbeda-beda. Seorang teolog akan mengatasi religiositas dari sudut pandang iman, seorang pendidik agama fokus pada ortodoksi dan keyakinan. Para psikolog mungkin memilih dari dimensi pengabdian, kesucian, dan kesalehan. Seorang sosiologi mempertimbangkan sebagai keanggotaan gereja, kehadiran di gereja, penerimaan, pengetahuan doktrinal, dan iman. ${ }^{25}$ Jadi, definisi religiositas dibuat berdasarkan disiplin ilmu akademis untuk mengidentifikasikan apa yang dapat dianggap seperti dimensi religiusitas. Engebretson menentukan religiositas sebagai tingkat komitmen kepada agamanya. ${ }^{26}$ Menurut Davis, religiositas mengimplikasikan kesetiaan pada suatu sistem tertentu akan kepercayaan, pemujaan, dan ketaatan pada satu set doktrin suci, ketaatan sebagai keanggotaan bersama orang-orang yang memiliki kepercayaan tentang Tuhan, ketaatan hidup suci, dan memiliki moralitas. ${ }^{27}$

Jadi, pengertian religiositas yang dipakai dalam penelitian ini adalah komitmen individu kepada Tuhan melalui agama yang diyakininya menjadi pedoman dalam melaksanakan kegiatan hidup sehari-hari sehingga menjadi pegangan dalam berpikir, bertindak, dan dalam segala aspek hidup sehari-hari. Keberagamaan yang dimiliki diperoleh melalui keyakinan dan pengetahuan yang mendalam sesuai yang diyakini individu tersebut.

\section{Penelitian Terdahulu}

\section{Empati dan pemaafan (forgiveness)}

Hasil penelitian yang dilakukan oleh Welton, Hill, dan Seybold bahwa empati menjadi alat prediksi yang terkuat akan forgiveness dan menyatakan bahwa empati merupakan peran yang lebih penting daripada kemarahan atau pengambilan perspektif. ${ }^{28}$ Namun kemungkinan lain, ukuran empati lebih akurat daripada ukuran kemarahan dan

\footnotetext{
${ }^{23} \mathrm{~B}$. Holdcroft, "Review of research what is religiosity?" Catholic Education: A Journal of Inquiry and Practice, 10, 89-103, 2006.

${ }^{24}$ Ibid.

${ }^{25}$ Ibid.

${ }^{26}$ C. J. Van Dyke, \& M. J Elias, "How forgiveness, purpose, and religiosity are related to mental health and well-being of youth: A review of the literature," Mental Health, Religion \& Culture, 10, 395-415, 2007

${ }^{27}$ Ibid.

${ }^{28}$ G. L. Welton, P. C. Hill, \& K. S. Seybold, "Forgiveness in the trenches: empathy, perspective taking, and anger," Journal of Psychology and Christianity, 27, 168-177, 2008.
} 
pengambilan perspektif. McCullough menyatakan bahwa empati membantu perkembangan forgiveness dapat dilaksanakan oleh transgresor kepada transgresi dan empati memfasilitasi pelaksanaan forgiveness sehingga semakin tinggi tingkat empati individu semakin mampu melakukan forgiveness. ${ }^{29}$ Dalam pengujian model hipotesis empati dengan forgiveness oleh McCullough, Worthington, dan Rachal menyatakan bahwa empati sebagai mediator untuk melakukan forgiveness. Maka, semakin tinggi tingkat empati individu semakin dapat melakukan forgiveness. ${ }^{30}$

Macaskill, John dan Liza, dalam penelitiannya menunjuk pada model perkembangan empati sebagai korban dapat melaksanakan forgiveness terhadap transgresor. ${ }^{31}$ Individu pada tingkat empati yang lebih tinggi merasa bahwa lebih mudah untuk melakukan forgiveness daripada mereka yang tingkatnya lebih rendah, dan individu yang tidak mampu berempati merasa sangat sulit untuk forgiveness. Pada penelitian Wade dan Worthington yang menggali prediktor yang potensial akan unforgiveness dan melakukan forgiveness untuk kejahatan khusus pada 91 lulusan. ${ }^{32}$ Penelitian analisa regresi untuk menentukan alat prediksi unforgiveness, dimana empati untuk pelaku kesalahan memberi kontribusi bagian yang signifikan $\mathrm{R}^{2}=.15, \mathrm{~F}(1,76)=18.40, p<.001, \beta=.464, t(77)=-4.29, p<.001$. Jadi, empati yang lebih tinggi pada transgresor diprediksikan lebih sedikit unforgiveness.

Lawler-Row, Younger, Piferi, dan Jones mengadakan penelitian kepada 108 mahasiswa psikologi di Universitas Tenesse, Knoxville. ${ }^{33}$ Tujuannya melihat peran gaya kasih orang dewasa (the role of adult attachment style) dalam tindakan memaafkan. Hasil penelitian menunjukkan pada ANOVA cukup signifikan: individu securely attached lebih pemaaf daripada individu insecurely attached, $F(1,104)=9.59, \rho<.003$, dan kelompok yang memiliki orang tua memiliki nilai frekuensi yang lebih tinggi daripada nonparents, $F$ $(1,104)=10.08, \rho<.002)$. Dalam pengujian model hipotesis empati dengan forgiveness oleh McCullough, Worthington, dan Rachal menyatakan bahwa empati sebagai mediator untuk melakukan forgiveness. ${ }^{34}$ Dari penelitian-penelitian yang telah dilakukan sebelumnya-seperti yang dilakukan McCullough, Worthington, dan Rachal, 1997; Macaskill, Maltby, dan Day, 2002; Toussaint \& Webb, 2005-empati menjadi salah satu variabel yang terbukti meningkatkan kemungkinan memaafkan. Penelitian lain menyatakan

\footnotetext{
${ }^{29}$ M. E. McCullough, "Forgiveness: who does it and how do they do it?" Current directions in psychological science, 10, 194-19, 72001.

${ }^{30}$ McCullough, Worthington, \& Rachal, "Interpersonal forgiving in close relationship"

${ }^{31}$ A. MacaskillM, John, Liza, "Forgiveness of self and others and emotional empathy," The Journal of Social Psychology, 142, 663-665, 2002.

${ }^{32}$ Wade and Worthington, "Overcoming interpersonal offenses: Is forgiveness the only way to deal with unforgiveness?"

${ }^{33}$ Lawler-Row, Younger, Jones, "The role of adult attachment style in forgiveness following an interpersonal offense"

${ }^{34}$ McCullough, Worthington, \& Rachal, "Interpersonal forgiving in close relationship,"
} 
bahwa empati memfasilitasi proses pengampunan ${ }^{35}$, empati biasanya menjadi topik dalam konseling yang didisain untuk meningkatkan forgiveness. ${ }^{36}$

Namun dari beberapa penelitian yang dilakukan mengenai empati, sangat sedikit studi yang menggambarkan mahasiswa teologi, sehingga penelitian yang dilakukan sebelumnya belum tentu bisa digeneralisasi kepada mahasiswa teologi Salatiga. Dari beberapa penelitian di atas, ada penelitian yang menemukan tidak ada hubungan, adanya hubungan yang signifikan dan tingkat perbedaan pada jender dimana wanita lebih forgiveness daripada pria. Empati sebagai mediator untuk melakukan forgiveness.

\section{Religiusitas dan forgiveness}

Religiositas telah ditemukan berhubungan dengan beragam hasil yang positif, termasuk forgiveness ${ }^{37}$; penurunan dalam perilaku kejahatan dan kriminal (Kerley, Matthews, dan Blanchard, 2005), dan berkontribusi pada hal-hal yang bersifat sosial (Will dan Cochran, 1995). Religiositas juga ditemukan berhubungan dengan beragam hasil negatif, seperti meningkatnya praduga ${ }^{38}$, tindakan diskriminasi. ${ }^{39}$ Penelitian kepada 475 umat Muslim, Kristen, dan Yahudi serta penganut gerakan sekuler untuk meneliti hubungan antara religiositas dengan forgiveness mengisi kuesioner berbasis internet (Fox \& Thomas, 2008).

Hasil menunjukkan bahwa religiusitas berhubungan secara positif dengan forgiveness. Kelompok agama secara signifikan melaporkan tingkah laku yang lebih tinggi dan tindakan proyektif untuk forgiveness dibanding kelompok sekuler. Penemuan ini mengesankan bahwa keyakinan (faith) menjadi prediktor terkuat pada religiusitas untuk forgiveness.

Selain itu, ada penelitian yang menemukan bahwa religiusitas memiliki peran dalam melakukan forgiveness, seperti yang dilakukan oleh Hui, Watkins, Wong, Sun ${ }^{40}$, memiliki hubungan positif dengan forgiveness ${ }^{41}$, di mana dalam segala kegiatan hidup sehari-hari selalu disesuaikan dengan nilai-nilai religius. Bronk mencatat bahwa banyak orang sedang menemukan jalan mereka ke suatu tujuan hidup melalui beberapa pengalaman religious. ${ }^{42}$

\footnotetext{
${ }^{35}$ V. Konstam, W. Holmes, \& B. Levine, "Empathy, Selfism, and coping as elements of the pasychology of forgiveness: a preliminary study," Counseling and Values, 47, 172-180, 2003

${ }^{36}$ Lawler-Row, Younger, Jones, "The role of adult attachment style in forgiveness following an interpersonal offense"

${ }^{37}$ Gorsuch \& Hao, "Forgiveness: an exploratory factor analysis and its relationships to religious variables."

${ }^{38}$ Bradley, The interconnection between religious fundamentalism, spirituality, and the four dimensions of empathy

${ }^{39}$ L. M. Jackson, \& V. N. Esses, "Of scripture and ascription: the relation between religious fundamentalism and intergroup helping," Personality and Social Psychology Bulletin, 23, 893-906, 1997.

${ }^{40}$ Hui, Watkins, Wong, \& Sun, "Religion and forgiveness from Hong Kong chinese perspective"

${ }^{41} \mathrm{McCullough}$, Worthington, \& Rachal, "Interpersonal forgiving in close relationship"

${ }^{42}$ Dyke \& Elias, "How forgiveness, purpose, and religiosity are related to mental health and well-being of youth: A review of the literature"
} 


\section{Empati dan Religiusitas sebagai Perdiktor pada Forgiveness}

Hingga saat ini, terdapat penelitian yang sangat minim pada hubungan religiusitasempati, bahkan tidak dengan variabel lain umpamanya seperti forgiveness. Penulis hanya menemukan review religius-empati. Hambatan lain yang signifikan untuk memahami hubungan antara religius dan empati adalah kurangnya kesepakatan dalam literatur tentang operasional konsep agama. ${ }^{43}$ Penelitian sebelumnya menunjukkan bahwa orientasi religius berhubungan positif dengan empati, tekanan personal. ${ }^{44}$ Dalam komitmen religius dihipotesakan akan mengekspresikan keadaan empati dan menghasilkan forgiveness yang lebih tinggi, dimana balas dendam yang rendah. ${ }^{45}$ Penelitian empiris telah menemukan bahwa religiusitas remaja berhubungan dengan empati, pandangan negatif dari penggunaan narkoba dan alkohol. ${ }^{46}$

Data-data penelitian yang telah disebutkan di atas, menunjukkan bahwa empati dan religiusitas dapat menjadi prediktor pada forgiveness secara parsial. Karena itu kerangka teoritik yang akan digunakan dalam penelitian ini adalah bahwa empati adalah prediktor pada forgiveness dan religiusitas juga menjadi prediktor pada forgiveness. Sedangkan penelitian-penelitian terdahulu memiliki perbedaan lingkungan dan situasi dengan sampel yang akan dilakukan pada saat ini. Ditambah penelitian ini juga akan melihat empati dan religiusitas secara simultan menjadi prediktor forgiveness pada mahasiswa. Maka, forgiveness dapat dilaksanakan bila terdapat empati yang tinggi serta religiusitas yang tinggi.

Sejauh penelusuran peneliti sampai saat penulisan ini belum menemukan adanya penelitian empati dan religiusitas secara simultan sebagai prediktor terhadap forgiveness pada mahasiswa. Hasil penelitian yang telah ada belum menunjukkan data yang komprehensif.

\section{Hipotesis}

Berdasarkan pembahasan definisi, aspek, faktor dan peranan serta landasan teori, maka hipotesis yang diajukan dalam penelitian ini adalah sebagai berikut: Empati dan religiusitas sebagai prediktor terhadap pemaafan pada mahasiswa Sekolah Tinggi Teologi Salatiga.

\section{METODE PENELITIAN}

\footnotetext{
${ }^{43}$ Bradley, The interconnection between religious fundamentalism, spirituality, and the four dimensions of empathy"

${ }^{44}$ Ibid.

${ }^{45}$ C.V.O. Witvliet, T.E., Ludwig \& K.L Vabder Laan, "Granting forgiveness or harboring grudges: Implications for emotion, psychology, and health,” Psychological Science, 12, 117-123, 2001.

${ }^{46}$ Dyke \& Elias, "How forgiveness, purpose, and religiosity are related to mental health and well-being of youth: A review of the literature"
} 
Penelitian ini dilakukan secara kuantitatif di mana terdapat dua variabel penelitian yaitu: empati dan religiositas. Populasi penelitian adalah seluruh siswa Sekolah Tinggi Teologi Salatiga sebanyak 85 tetapi yang tidak hadir saat pengisian angket sebanyak 11 siswa dan 3 siswa tidak diikutsertakan berhubung mereka berada di luar batas usia penelitian. Maka jumlah seluruh mahasiswa adalah 71 orang.

Penelitian ini menggunakan instrumen penelitian dan alat ukur seperti skala forgiveness, skala empati, dan skala religiositas. Untuk mengetahui pemaafan mahasiswa digunakan skala Pemaafan (forgiveness) diadaptasi dari Transgression-Related Interpersonal Motivation Inventory (TRIM) ${ }^{47}$ yang telah mengalami modifikasi oleh peneliti sesuai dengan tujuan penelitian, yang disusun berdasarkan teori yang dikemukakan oleh McCullough. Dan skala Vabsteebwegen, Enright \& Stroobants, 2007. Makin tinggi skor total yang diperoleh menunjukkan tingginya level pemaafan individu. Dan makin rendah skor total yang diperoleh menunjukkan rendahnya level pemaafan individu. Aspekaspek empati meliputi Pengambilan perspektif, Imajinasi, Perhatian Empatik dan Distres Pribadi. Alat ukur aspek empati yaitu menggunakan skala empati yang diadopsi dari tesis Yulia dibuat oleh Davis dengan tingkat realibitas 0.842 dan yang dimodifikasi oleh penulis sesuai dengan tujuan penelitian. ${ }^{48}$ Penilaian skala empati ini makin tinggi skor total yang diperoleh individu menunjukkan semakin tinggi empatinya semakin dapat melakukan forgiveness.

Skala Religiositas disusun berdasarkan Glock dan Stark yang telah dimodifikasi oleh peneliti sesuai dengan tujuan penelitian. ${ }^{49}$ Dimensi-dimensi religiusitas meliputi praktek, keyakinan, pengalaman religius, dan konsekuensi. Semakin tinggi skor menunjukkan semakin dapat melakukan pemaafan. Makin tinggi skor total yang diperoleh menunjukkan tingginya level religiusitas individu. Dan makin rendahnya skor total yang diperoleh menunjukkan rendahnya level religiusitas individu.

Sebelum penelitian dilaksanakan maka dilakukan uji coba (try out) terhadap alat ukur penelitian dengan menyebarkan skala Pemaafan, skala Empati dan skala Religiusitas. Tempat uji coba dilaksanakan di empat tempat yaitu STT Nusantara 1 (10 lembar isian), STT Efata (26 lembar isian), STT Nusantara 2 (11 lembar isian), Kelompok Persekutuan Pemuda Remaja/Mahasiswa GKI - Soka, Salatiga (44 lembar isian). Skor untuk setiap jawaban diolah dengan menggunakan SPSS 16 termasuk melaskukan seleksi aitem dan

\footnotetext{
${ }^{47} \mathrm{McCullough}$, Root, \& Cohen, "Writing about the personal benefits of transgression facilitates forgiveness"

${ }^{48}$ Yulia, "Empati dan pola asuh demokratis sebagai prediktor pada perilaku prososial anak-anak di pusat pengembangan anak Solo,” Tesis (Salatiga: Universitas Kristen Satya Wacana Salatiga, 2012).

${ }^{49}$ J. Reitsma, P. Scheepers, \& M. Te Grotenhuis, "Dimensions of individual religiosity and charity: cross-national effect differences in european countries?" Review of Religious Research, 47, 347-362, 2006
} 
menghitung reliabilitas masing-masing skala. Didapati beberapa aitem yang tidak layak dipakai lalu melakukan perbaikan pengalimatan dan urutan nomor yang baru pada item yang layak dipakai.

Langkah-langkah selanjutnya meliputi: Analisa item (daya diskriminasi item) dan uji reliabilitas; uji asumsi klasik seperti: uji normalitas, uji linearitas, uji multikolonieritas, uji heteroskedastisitas dan uji hipotesis. Dalam penelitian ini, perhitungan daya beda aitem dan reliabilitas dilakukan dengan teknik koefisien Alpha Cronbach menggunakan SPSS for windows evaluation version 17.

Pedoman penilaian skala reliabilitas

\begin{tabular}{|c|c|}
\hline Alpha & Kriteria \\
\hline $0,00-0,199$ & Sangat rendah \\
\hline $0,20-0,399$ & Rendah \\
\hline $0,40-0,599$ & Sedang \\
\hline $0,60-0,799$ & Kuat \\
\hline $0,80-1,000$ & Sangat kuat \\
\hline
\end{tabular}

\section{HASIL DAN PEMBAHASAN}

Seleksi item pada masing-masing skala pada tahap pertama akan dilanjutkan pada tahap kedua, dan bila perlu akan dilanjutkan. Skala Pemaafan ditemukan seluruh aitem (55) valid dengan reliabilitas 0,939 artinya seluruh item memiliki daya diskriminasi yang baik dan dapat digunakan untuk mengukur variabel Pemaafan. Skala Empati ditemukan seluruh aitem (19) valid dengan reliabilitas 0,841 artinya seluruh aitem memiliki daya diskriminasi yang baik dan dapat digunakan untuk mengukur variabel empati serta dapat diandalkan dalam penelitian ini. Pada skala Religiusitas ditemukan satu item yang gugur pada nomor 18 dengan reliabilitas 0,882 , sehingga jumlah aitem menjadi 22. Dan sekali lagi skala religiositas dilakukan pengujian yang ketiga, maka ditemukan seluruh item valid dengan reliabilitas 0,882 . Artinya seluruh item memiliki daya diskriminasi yang baik dan dapat digunakan untuk mengukur variabel religiusitas dalam penelitian ini.

\section{Analisa Data}

Uji Normalitas, hasil menyatakan bahwa titik-titik menyebar di sekitar garis diagonal, serta penyebarannya mengikuti arah garis diagonal. Maka, model regresi layak dipakai untuk memprediksikan firgiveness berdasarkan masukan variabel empati dan religiusitas sebagai variabel independen. Selanjutnya pada One-Sample Kolmogorov-Smirnov dilihat KSZ sebesar 0,697, $p<0.05$. Maka dapat dikatakan bahwa Nilai residual normal dan memenuhi asumsi untuk menggunakan analisis regresi. Pada histogram memperlihatkan 
grafik mengikuti sebaran kurva normal, dimana kurva berbentuk lonceng yang tidak melenceng ke kiri atau ke kanan.

Hasil uji linearitas antara variabel empati terhadap forgiveness dapat dilihat pada ANOVA Table bahwa nilai F sebesar 23.016 dengan signifikansi $0.000(\mathrm{p}<0.05)$, maka dapat disimpulkan bahwa empati dan forgiveness memiliki hubungan yang linear. Sedangkan uji analisis varians Religiusitas denganforgiveness dengan nilai $\mathrm{F}$ sebesar 31.059 dengan signifikansi $0.000(\mathrm{p}<0.05)$, maka disimpulkan bahwa religiusitas dengan forgiveness memiliki hubungan yang linear.

Uji multikolinearitas. Adapun nilai tolerance dan VIF empati dan religiusitas di sekitar angka 1. Maka model regresi tersebut tidak terdapat masalah multikolinearitas. Koefisien korelasi empati dengan religiusitas terlihat sebesar -0.493 jauh di bawah 0.50 , artinya antar variabel bebas tidak terjadi multikolinearitas. Uji Heterokedastisitas. Pada gambar Scatterplot terlihat titik-titik menyebar secara acak, tidak membentuk sebuah pola yang jelas dan tersebar baik di atas maupun di bawah angka 0 pada sumbu Y. Hasil Analisa Data. Hasil Uji Anova Empati dan Religiusitas terhadap Pemaafan didapat nilai Fhitung sebesar 13.999 dengan tingkat signifikansi 0.000. Oleh karena probabilitas signifikansi lebih kecil dari 0.05 maka dapat disimpulkan bahwa model regresi ini dapat digunakan untuk memprediksi Forgiveness.Dapat disimpulkan bahwa empati (X1) dan religiusitas (X2) secara simultan menjadi prediktor forgiveness (Y).

Dari tampilan PASW Statistic 17, besarnya R square $\left(\mathrm{R}^{2}\right)$ adalah 0.292 . Hal ini berarti bahwa $29.2 \%$ dari variasi yang terjadi pada $\mathrm{Y}$ dapat dijelaskan oleh kedua variabel independen, yaitu empati dan religiusitas, sisanya $70.8 \%$ dijelaskan oleh variabel lain yang tidak dapat dijelaskan karena berada di luar jangkauan penelitian. Ringkasan sumbangan efektif dari tiap prediktor bahwa empati memberi pengaruh yang signifikan sebesar 9.9\% ( $\beta$ $=0.234)$ dan religiusitas memberi pengaruh yang signifikan sebesar $19.3 \%(\beta=0.385)$.

Selanjutnya hasil uji signifikansi pamameter individual pada variabel empati sebesar 0.050 dan religiusitas sebesar 0.002. Dengan demikian dapat dikatakan bahwa X1 secara parsial menjadi prediktor yang signifikan terhadap $Y(t-1,994, p<0.005)$ dan X2 juga secara parsial menjadi prediktor yang signifikan terhadap $Y(t-3,283, p<0.005)$. Susunan persamaan regresi sebagai berikut:

$$
\begin{gathered}
\mathrm{Y}=\beta+\beta \mathrm{X} 1+\beta \mathrm{X} 2 \\
=47.856+0.693 \text { empati }+0.957 \text { religiusitas }
\end{gathered}
$$

Keterangan 
- Konstanta sebesar 47.856 menyatakan bahwa jika variabel independen dianggap konstan, maka nilai variabel Pemaafan sebesar 47.856 pada interval dengan kategori sangat rendah dan juga dapat dikategorikan rendah.

- Koefisien regresi empati sebesar 0.693 memberikan pemahaman bahwa setiap penambahan satu satuan atau satu tingkatan empati merupakan faktor penambahan yang akan berdampak pada meningkatnya pemaafan sebesar 0.693 satuan juga.

- Koefisien regresi religiusitas sebesar 0.957 memberikan pemahaman bahwa setiap penambahan satu satuan atau satu tingkatan religiusitas merupakan faktor penambahan yang akan berdampak pada meningkatnya pemaafan sebesar 0.957 satuan juga.

Hipotesis yang menyatakan bahwa empati dan religiusitas secara simultan menjadi prediktor pemaafan dinyatakan diterima. Hal ini berarti bahwa empati dan religiusitas bersama-sama menjadi prediktor bagi pemaafan siswa. Hal ini diduga disebabkan motivasi niat baik dan prososial serta emosi positif siswa dimunculkan dari agama yang diyakininya. Selain itu, empati juga menjadi variabel yang memahami perasaan bersalah atas tindakan yang menyakitkan serta membuat individu dapat memperbaiki hubungan yang telah retak.

Hasil penelitian ini sejalan dengan penelitian-penelitian sebelumnya dari Tsang, religiusitas yang membangkitkan emosi positif seperti kasih, empati, memungkinkan terwujudnya pemaafan. ${ }^{50}$ Agama yang dianut individu dapat mempromosikan pemaafan dengan mendorong empati siswa yang menjadi dasar sebagai elemen dalam mewujudkan pemaafan sehingga individu dengan tingkat empati yang tinggi lebih mudah untuk melakukan pengampunan kepada pihak lain. ${ }^{51}$ Individu memiliki kemampuan memahami emosi orang lain untuk menanggapinya dapat melakukan forgiveness. ${ }^{52}$ Lebih daripada itu, empati dan religiusitas secara positif berpengaruh terhadap pemaafan khususnya dalam hubungan interpersonal. Hasil yang positif dalam religiositas memampukan siswa melakukan forgiveness ${ }^{53}$, memiliki kesehatan yang positif (Levin, 1996) dan hubungan yang pulih kembali.

Mahasiswa yang dapat berbuat baik dengan tidak membalas dendam dan tidak menghindar transgresor memungkinkan mahasiswa dapat menyelesaikan permasalahan hubungan interpersonalnya secara positif. Hal ini sejalan dengan teori McCullough bahwa kemampuan merasakan kesulitan orang lain secara positif, yang disertai dengan penerapan

\footnotetext{
${ }^{50}$ McCullough, Bono, \& Root, "Religion and forgiveness"

${ }^{51}$ Konstam, Holmes, \& Levine, "Empathy, Selfism, and coping as elements of the pasychology of forgiveness: a preliminary study"

${ }^{52}$ C.S. Henry, S.W. Plinkett, L.C. Robinson, E.L. Huey\& B. McMichael, “Adolescent religious motivation, family functioning, and empathic concern," Journal of Religion ang Spirituality in Social Work, 28, 343-361, 2009

${ }^{53}$ Gorsuch \& Hao, "Forgiveness: an exploratory factor analysis and its relationships to religious variables," Band: McCullough, Root, \& Cohen, "Writing about the personal benefits of transgression facilitates forgiveness."
} 
agama yang benar memberikan kemampuan melakukan pemaafan. ${ }^{54}$ Mahasiswa yang melakukan penerapan agama dengan benar serta dapat mengerti perasaan individu yang lain dapat menekan rasa dendam untuk membalas transgresor dan tidak menghindar yang disertai dengan emosi positif.

Menurut teori ini, mahasiswa yang dapat berbuat baik dengan tidak menghindar dan mendendam terjadi pada saat mengerti perasaan orang lain dan di dukung oleh pemahaman agama dengan dimensi-dimensi tertentu yang berakumulasi dalam perasaan positif yang dialaminya, sehingga pada saat berinteraksi dengan lingkungan sosial dapat memulihkan hubungan yang retak. Dengan kata lain, empati dan religiusitas sama-sama menjadi prediktor yang signifikan bagi pemaafan mahasiswa. Kedua variabel itu merupakan faktor internal dan eksternal yang memberikan pengaruh terhadap pemaafan yang berdampak pada hubungan interpersonal.

Teori McCulough melihat bahwa domain-domain penting dalam kehidupan seseorang sebagai individu perlu diperhatikan dalam rangka meningkatkan hubungan yang baik kembali. Dalam hal ini, pada masa sebagai mahasiswa, memahami perasaan orang lain dan pemahaman agama yang lebih dalam merupakan dua bagian penting yang menjadi dasar dalam tugas missi sebagai calon pendeta. Dua bagian ini biasa memberikan dampak positif pada mahasiswa tergantung perlakuan yang mereka terima dari sebelumnya melalui keluarga dan komunitasnya. Sehingga apabila seseorang memahami perasaan terhadap yang lain serta pemahaman ajaran agama yang dianutnya dapat memberikan efek langsung dalam diri individu tersebut.

Oleh karena itu, dapat diargumentasikan bahwa dengan adanya empati dan religiositas, maka mahasiswa dapat melakukan pemaafan mengingat setiap orang ingin memiliki hubungan yang baik untuk seterusnya sebagai mahluk sosial sekalipun tidak luput dari hubungan yang bersinggungan. Di samping empati dan religiositas yang secara simultan menjadi prediktor pemaafan, namun secara parsial masing-masing menjadi prediktor yang signifikan bagi pemaafan mahasiswa. Hasil ini dapat dilihat melalui uji $\mathrm{t}$ yang memperlihatkan bahwa empati mejadi prediktor yang signifikan $(\beta=0.693)$ dan religiusitas $(\beta+0.951)$. Dari hasil tersebut, bisa dilihat bahwa religiositas memiliki nilai sigbifikan yang lebih tinggi dibandingkan empati, sehingga bisa dinyatakan bahwa mahasiswa akan dapat memiliki hubungan yang baik dan memiliki pemaafan yang tinggi apabila mereka memiliki religiositas.

Selain religiositas, dalam penelitian ini ditemukan bahwa empati juga menjadi prediktor pemaafan mahasiswa. Hasil penelitian ini juga konsisten dengan penelitian yang

\footnotetext{
${ }^{54} \mathrm{McCullough}$, Root, \& Cohen, "Writing about the personal benefits of transgression facilitates forgiveness."
} 
menemukan bahwa empati sebagai indikator yang mempunyai hubungan dengan pemaafan. ${ }^{55}$ Welton dan Hill (2008) menemukan hasil bahwa empati sebagai prediktor signifikan pada pemaafan. ${ }^{56}$ Dari hasil penelitian yang dilakukan dan dengan dukungan dari penelitian-penelitian terdahulu, maka dapat dikatakan bahwa empati dan religiusitas menjadi prediktor yang bisa melakukan pemaafan mahasiswa. Jika keduanya tinggi, maka pemaafan siswa akan tinggi dan bersifat positif.

\section{KESIMPULAN}

Berdasarkan uraian dan hasil penelitian, maka dapat ditarik kesimpulan sebagai berikut: Pertama, Empati dan religiusitas secara simultan menjadi prediktor pemaafan. Kedua, Religiusitas memberikan sumbangan yang lebih besar pada pemaafan dibandingkan empati. Adapun saran bagi lembaga pendidikan STT agar menjadi lembaga memberikan perhatian dalam perkembangan dan pemahaman agama yang baik melalui para dosen dan membantu siswa dalam empati dan meningkatkan nilai-nilai religiusitas. Bagi penelitian selanjutnya, dapat mengembangkan penelitian dengan variabel lain seperti sosial kognitif, pola asuh orang tua, personality, dan lainnya. Metode penelitiannya juga dapat dilanjutkan dengan metode kualitatif serta kualitatif dan kuantitatif.

\section{REFERENSI}

Bradley, C. "The interconnection between religious fundamentalism, spirituality, and the four dimensions of empathy," Review of Religious research, 51, 201-219, 2008.

Enright, R. D., \& Coyle, C. T. "Researching the process model of forgiveness within psychological interventions," Dalam E. L. Wothington, Jr. (Ed.), Dimensions of forgiveness: Psychological research and theological perspectives (pp.139-161). Philadelphia: Templeton Foundation Press, 1998.

Enright, R. D., Gassin, E. A., \& Wu, C. "Forgiveness: A development view," Journal of Moral Development, 21, 99-114, 1992.

Eisenberg, N. Empathy and its development (New York: Cambridge University Press., 2002)

Gorsuch, R. L., \& Hao, J. Y. "Forgiveness: an exploratory factor analysis and its relationships to religious variables," Review of religious Research, 34, 333-347, 1993.

Henry, C.S., Plinkett, S.W., Robinson, L.C., Huey, E.L., \& McMichael, B.J.“Adolescent religious motivation, family functioning, and empathic concern," Journal of Religion ang Spirituality in Social Work, 28, 343-361, 2009.

Holdcroft, B. "Review of research what is religiosity?" Catholic Education: A Journal of Inquiry and Practice, 10, 89-103, 2006.

Hui, E. K. P., Watkins, D., Wong, T. N. Y., \& Sun, R. C. F. "Religion and forgiveness from Hong Kong chinese perspective," Pastoral Psychology, 55, 183-195, 2006.

\footnotetext{
${ }^{55} \mathrm{McCullough,} \mathrm{Worthington,} \mathrm{\&} \mathrm{Rachal,} \mathrm{"Interpersonal} \mathrm{forgiving} \mathrm{in} \mathrm{close} \mathrm{relationship"}$

${ }^{56}$ Welton, Hill, \& Seybold, "Forgiveness in the trenches: empathy, perspective taking, and anger."
} 
Jackson, L. M. \& Esses, V. N. "Of scripture and ascription: the relation between religious fundamentalism and intergroup helping," Personality and Social Psychology Bulletin, 23, 893-906, 1997.

Jose, O. A., \& Alfons, V. "Religiosity and forgiveness among first-married and remarried adults," Mental Health, Religion \& Culture, 10, 379-394, 2007.

Konstam, V., Holmes, W., \& Levine, B. "Empath, Selfism, and coping as elements of the pasychology of forgiveness: a preliminary study," Counseling and Values, 47, 172180, 2003.

Lawler-Row, K. A., Younger, J. W., Piferi, R. L., \& Jones, W. H. "The role of adult attachment style in forgiveness following an interpersonal offense," Journal of Counseling \& Development, 84, 493-500, 2006.

Macaskill, A. "Defining forgiveness: Christian clergy and general population perspectives," Journal of Personality.73, 1238-1263, 2005.

Macaskill, A., John, M., \& Liza, D. "Forgiveness of self and others and emotional empathy" The Journal of Social Psychology, 142, 663-665, 2002.

McCullough, M. E. Forgiveness: who does it and how do they do it? Current directions in psychological science, 10, 194-197, 2001.

McCullough, M. E., Bono, G., \& Root, L.M. "Religion and forgiveness," Dalam R. F. Paloutzian \& C. L. Park (Eds.), Handbook of the psychology of religion and spirituality (pp. 394-411). New York: The Guilford Press, 2005.

McCullough, M. E., Root, L. M., \& Cohen, A. D. "Writing about the personal benefits of transgression facilitates forgiveness," Journal of Consulting and Clinical Psychology, 74, 887-897, 2006.

McCullough, M. E., Worthington, E. L. Jr., \& Rachal, K. C. "Interpersonal forgiving in close relationship," Journal of Personality and Social Psychology, 73, 321-336, 1997.

Reitsma, J., Scheepers, P., \& Te Grotenhuis, M. "Dimensions of individual religiosity and charity: cross-national effect differences in european countries?" Review of Religious Research, 47, 347-362, 2006.

Sandage, S. J., \& Williamson, I. "Relational spirituality and dispositional forgiveness: a structural equations model," Journal of Psychology and Theology, 38, 255-266, 2010

Van Dyke, C. J., \& Elias, M. J. "How forgiveness, purpose, and religiosity are related to mental health and well-being of youth: A review of the literature," Mental Health, Religion \& Culture, 10, 395-415, 2007.

Wade, N. G., \& Worthington, E. L. Jr. "Overcoming interpersonal offenses: Is forgiveness the only way to deal with unforgiveness?" Journal Of Counseling \& Development Summer, 81, 2003

Welton, G. L., Hill, P. C., \& Seybold, K. S. "Forgiveness in the trenches: empathy, perspective taking, and anger," Journal of Psychology and Christianity, 27, 168-177, 2008.

Witvliet, C., v. O., Hinze, S. R., \& Worthington, E. L. Jr. "Unresolved injustice: Christian religious commitment, forgiveness, revenge, and cardiovascular responding," Journal of Psychology and Christianity, 27, 110-119, 2008.

Witvliet, C.V.O., Ludwig, T.E., \& Vabder Laan, K.L. "Granting forgiveness or harboring grudges: Implications for emotion, psychology, and health," Psychological Science, 12, 117-123, 2001. 
Wohl, M. J. A., DeShea, L., \& Wahkinney, R. L. "Looking within: measuring state selfforgiveness and its relationship to psychological well-being," Canadian Journal of Behavioural Science, 40, 1-10, 2008.

Worthington, E. L. Jr. Handbook of forgiveness, New York: Routledge, 2005.

Worthington, E. L. Jr., Sharp, C. B., Lerner, A. J., \& Sharp, J. "Interpersonal forgiveness as an example of loving one's enemies," Journal of Psychology and Theology, 34, 32-42, 2006.

Worthington, E. L. Jr. "Empirical research on forgiveness with Christians: What have we learned?" Journal of Psychology and Christianity, 27, 368-370, 2008.

Yulia. "Empati dan pola asuh demokratis sebagai prediktor pada perilaku prososial anakanak di pusat pengembangan anak Solo," Tesis, Salatiga: Universitas Kristen Satya Wacana Salatiga, 2012. 